\title{
Udział sekretarzy ab epistulis i a libellis w procesie tworzenia reskryptów cesarskich
}

Czy cesarze rzymscy okresu pryncypatu osobiście czytali prośby adresowane do nich, czy odpisywali na zapytania, a jeśli nie, to kto czynił to za nich? Można zapytać expressis verbis, czy cesarze osobiście tworzyli reskrypty? Jedynie próba odpowiedzi na tak postawione pytania jest w stanie wyjaśnić nam mechanizmy funkcjonowania aparatu biurokratycznego w Cesarstwie Rzymskim. We współczesnym państwie nie ma sprawnego funkcjonowania najważniejszych organów monokratycznych bez skutecznie działającej kancelarii. Podobnie było w Cesarstwie Rzymskim. Grupa prywatnych i wyspecjalizowanych sług, a następnie urzędników cesarskich stanowiła podstawę działania administracji już za czasów Imperium Romanum. Cesarz Klaudiusz utworzył kancelarię jako pomocniczy organ biurokratyczny, kierowany przez wyzwoleńców cesarskich. Dopiero za panującego w latach 117-138 cesarza Hadriana kancelaria cesarska została przekształcona w urząd państwowy kierowany przez ekwitów, którzy podlegali określonym zasadom awansu w ramach ekwickiego cursus honorum ${ }^{1}$. O ogromnym znaczeniu urzędników kancelarii cesarskiej świadczy fakt, że byli oni powoływani i odwoływani przez cesarza, przez niego również wynagradzani.

1 Pojawiające się w niniejszej pracy daty, jeśli nie zaznaczono, że jest inaczej, odnoszą się do czasów po narodzeniu Chrystusa. 
Kancelaria cesarska jest przedmiotem badań zarówno romanistów, jak i historyków już od drugiej połowy XIX wieku². Badania te dotyczą głównie struktury kancelarii, kompetencji urzędników oraz w mniejszym stopniu prozopografii. Na podstawie źródeł prawnych, literackich oraz epigraficznych postaram się przedstawić udział sekretarzy do spraw korespondencji (ab epistulis) i do spraw petycji (a libellis) w procesie tworzenia prawa stanowionego okresu

2 É. Egger, Recherches historiques sur la fonction de secrétarie des princes chez les anciens, [w:] Mémoires d'histoire ancienne et de philologie, Paris 1863, s. 220-258; J.N. Madvig, Die Verfassung und Verwaltung des Römischen Staates, Bd. I, Leipzig 1881, s. 553-561; É. Cuq, Le Conseil des Empereurs d'Auguste à Dioclétien, Extrait des Mémoires présentés par divers savants à l'Académie des Inscriptions et Belles-Lettres, I Sér. IX, 2, Paris 1884, s. 361-401; Th. Mommsen, Römisches Staatsrecht, Bd. II, 2, Handbuch der römischen alterthümer, ed. J. Marquardt, Th. Mommsen, Leipzig 1877, s. 806-810; O. Hirschfeld, Untersuchungen auf dem Gebiete der römischen Verwaltungsgeschichte, I: Die kaiserlichen Verwaltungsbeamten bis auf Diocletian, Berlin-Weidmann 1877, s. 201-218; O. Karlowa, Römische Rechtsgeschichte, Bd. I, Leipzig 1885, s. 538-547; L. Friedlaender, Darstellungen aus der Sittengeschichte Roms in der Zeit. Von August bis zum Ausgang der Antonine, t. I, Leipzig 1888 (6 Aufl.), s. 171-192; A.H.J. Greenidge, Roman Public Life, London-New York 1901, s. 418-420; Th. Mommsen, Gordians Decret von Skaptoparene, [w:] Gesammelte Schriften, Bd. II, Juristische Schriften, Bd. II, Berlin-Weidmann 1905, s. 172-192; O. Hirschfeld, Die kaiserlichen Verwaltungsbeamten bis auf Diocletian, Berlin 1905 (2 Aufl.), s. 318-342; M.I. Rostowzew, s.v. ab epistulis, [w:] Realencyclopädie der classischen Altertumswissenschaft (dalej: RE) VI, 1, 1907, col. 210-215; S. Brassloff, s.v. epistula, RE VI, 1909, col. 204-210; F.F. Abott, History and Description of Roman Political Institutions, New York 1911 (3rd ed.), s. 362; U. Wilcken, Zu den Kaiserreskripten, Hermes. Zeitschrift für classische Philologie, Bd. 55, 1920, s. 1-42; O. Seeck, s.v. Scrinium, RE II A, 1, 1921, col. 893-904; A. v. Premerstein, s.v. a libellis, RE XIII, 1, 1927, col. 15-26; B. Kübler, s.v. subscriptio, RE IV, 1, 1931, col. 490-501; G. Samonati, s.v. a libellis, Diz. epigr., IV, 1957, s. 822-828; R. Paribeni, s.v. ab epistulis, Diz. epigr., II/III, 1961, s. 2132-2135; G.B. Townend, The Post of $a b$ epistulis in the Second Century, Historia. Zeitschrift für Alte Geschichte 1961, 10, s. 375-381; F. Millar, Emperors at Work, The Journal of Roman Sudies 1967, 57, s. 9-19; W. Williams, The Libellus Procedure and the Severan Papyri, The Journal of Roman Studies 1974, 64, s. 86-103; W. Williams, Individuality in the Imperial Constitutions: Hadrian and the Antonines, The Journal of Roman Studies 1976, 66, s. 67-83; F. Millar, The Emperor in the 
pryncypatu. Wybór tych dwóch sekretariatów nie jest przypadkowy, gdyż jedynie sekretarze do spraw korespondencji i do spraw petycji byli aktywni w kreowaniu cesarskich konstytucji ${ }^{3}$.

Jakie akty prawne stanowiły konstytucje cesarskie okresu pryncypatu i które $\mathrm{z}$ nich były tworzone w sekretariatach do spraw korespondencji i do spraw petycji? Najstarszym, jak sądzę, przekazem prawniczym na temat źródeł prawa cesarskiego jest fragment Institutiones Gajusa.

Gaius, Institutiones 1, 5:

Constitutio principis est, quod imperator decreto vel edicto, vel epistula constituit. Nec umquam dubitatum est, quin id legis vicem optineat, cum ipse imperator per legem imperium accipiat.

W połowie II wieku Gajus wymienił dekrety, edykty i listowne odpowiedzi jako konstytucje cesarskie. Wybitny jurysta wskazał na ich moc prawną oraz na fakt, że władza cesarska jest nadana przez ustawę. Wnioskując na postawie relacji Gajusa, można stwierdzić bez żadnej wątpliwości, że konstytucje cesarskie są ekwiwalentem prawa stanowionego.

Roman World, 31 BC-AD 337, London 1977; A.A. Schiller, Roman law: Mechanisms of Development, Hague 1978, s. 474-480; T. Honoré, 'Imperial' Rescripts A.D. 193-305: Authorship and Authenticity, The Journal of Roman Studies 1979, 69, s. 51-64; T. Honoré, Emperors and lawyers, London 1981; M. Peachin, The Office of the Memory, [w:] Studien zur Geschichte der römischen Spätantike. Festgabe für Johannes Straub, ed. E. Chrysos, Athens 1989, s. 168-208; W. Turpin, Imperial Subscriptions and the Administration of Justice, The Journal of Roman Studies 1991, 81, s. 101-118; J.-P. Coriat, Le prince législateur. La technique législative des Sévères et les méthodes de création du droit impérial a la fin du Principat, Roma 1997; A. Berger, Enciclopedic Dictionary of Roman Law, New Jersey 2004 (wyd. org. Philadelphia 1953), s. 338; D. Liebs, Reichskummerkasten: Die Arbeit der kaiserlichen Libellkanzlei, [w:] Herrschaftsstrukturen und Herrschaftspraxis - Konzepte, Prinzipien und Strategien der Administration im römischen Kaiserreich, ed. Anne Kolb, Berlin 2006, s. 137-152; K. Kłodziński, Sekretarze ab epistulis $i$ a libellis $w$ kancelarii cesarzy od Augusta do Hadriana. Studium historyczno-prawne, Toruń 2011.

${ }^{3}$ Por. W. Williams, Individuality, s. 68; A.A. Schiller, Roman law, s. $478-479$. 
Kolejne informacje są przekazane przez Pomponiusza - jurystę z czasów Hadriana, Antoninusa Piusa i Marka Aureliusza.

D. 1, 2, 2, 11-12 (Pomponius libro singulari enchiridii):

Novissime sicut ad pauciores iuris constituendi vias transisse ipsis rebus dictantibus videbatur per partes, evenit, ut necesse esset rei publicae per unum consuli (nam senatus non perinde omnes provincias probe gerere poterant): igitur constituto principe datum est ei ius, ut quod constituisset, ratum esset. Ita in civitate nostra aut iure, id est lege, constituitur, aut est proprium ius civile, quod sine scripto in sola prudentium interpretatione consistit, aut sunt legis actiones, quae formam agendi continent, aut plebi scitum, quod sine auctoritate patrum est constitutum, aut est magistratuum edictum, unde ius honorarium nascitur, aut senatus consultum, quod solum senatu constituente inducitur sine lege, aut est principalis constitutio, id est ut quod ipse princeps constituit pro lege servetur.

Ten passus autorstwa Pomponiusza przedstawia ewolucyjny charakter prawa rzymskiego, którego ostateczny kształt został nadany przez władzę pryncepsa. W civitas konstytucje cesarskie formułowane przez samego cesarza, obok jurysprudencji prawniczej, postępowań sądowych, plebiscytów, edyktów urzędniczych oraz uchwał senatu mają moc prawną. W opinii Pomponiusza konstytucje cesarskie są postrzegane jako źródła prawa stanowionego.

Również prawnik pierwszych cesarzy z dynastii Sewerów Papinian przekazał nam istotne informacje.

D. 1, 1, 7 (Papinianus libro secundo definitionum):

Ius autem civile est, quod ex legibus, plebis scitis, senatus consultis, decretis principum, auctoritate prudentium venit.

Papinian twierdził, że dekrety cesarskie, obok plebiscytów, uchwał senatu i prawotwórczej działalności jurystów, to źródła prawa cywilnego. Natomiast według Ulpiana prawo stanowione to stricte cesarskie prawo, a konstytucja ma tę samą moc, co ustawa. 
D. 1, 4, 1 (Ulpianus libro primo institutionum):

Quod principi placuit, legis habet vigorem: utpote cum lege regia, quae de imperio eius lata est, populus ei et in eum omne suum imperium et potestatem conferat.

$Z$ powyższych rozważań wynika, że rescripta, obok decreta, edicta, mandata należy uznać za konstytucje cesarskie, czyli źródła prawa stanowionego okresu pryncypatu ${ }^{4}$. Prawo okresu pryncypatu to głównie prawo stanowione przez cesarza ${ }^{5}$. Rescripta principum, czyli cesarskie odpowiedzi, były niezwykle ważne w systemie prawnym pryncypatu $^{6}$. Reskrypty przyjmowały dwie odmienne formy: epistulae $^{7}$ oraz subscriptiones ${ }^{8}$.

\section{1, 4, 1, 1 (Ulpianus libro primo institutionum):}

Quodcumque igitur imperator per epistulam et subscriptionem statuit vel cognoscens decrevit vel de plano interlocutus est vel edicto praecepit, legem esse constat. Haec sunt quas volgo constitutiones appellamus.

Według Ulpiana postanowienie cesarskie w formie listu (epistula) lub noty (subscriptio) albo to, co cesarz zdecydował w formie wyroku

4 Por. L. Wenger, Die Quellen des römischen Rechts, Wien 1953, s. 424-438; W. Wołodkiewicz, Ius et lex $w$ rzymskiej tradycji prawnej, Ius et Lex 2002, 1, s. 54. Mandata, czyli administracyjne instrukcje, zostały zaliczone do kategorii konstytucji cesarskich przez współczesnych uczonych, por. A.A. Schiller, Roman law, s. 481.

5 O.F. Robinson, The Sources of Roman Law: Problems and Methods for Ancient Historians, London 1997, s. 37.

6 D. Ibbetson, High classical law, [w:] Cambridge Ancient History, vol. XII: The Crisis of Empire, A.D. 193-337, Cambridge 2005, s. 196. Nazwa rescriptum była używana na określenie dwóch form konstytucji - epistulae i subscriptiones, por. W.W. Buckland, A Textbook of Roman Law from Augustus to Justinian, Cambridge 1964 (wyd. org. Cambridge 1921), s. 19; W. Turpin, Imperial, s. 103; The Oxford Latin Dictionary, ed. P.G. W. Glare, Oxford-New York 1996 (dalej: OLD), s.v. rescriptum, s. 1627.

7 A. Berger, Enciclopedic, s.v. epistulae principum, s. 454; OLD, s.v. epistula, s. 613.

8 A. Berger, Enciclopedic, s.v. subscriptio principis, s. 720-721; OLD, s.v. subscriptio, s. 1848. 
sądowego lub ogłosił nieformalnie czy też nadał edyktem, ma moc prawną i stanowi konstytucję. Procedura prawotwórcza w przypadku epistulae i subscriptiones jest identyczna9 ${ }^{9}$. Regułą było, że epistulae principum stanowiły odpowiedzi na pytania lub petycje miast, namiestników prowincji oraz innych urzędników, natomiast subscriptiones były powszechną w II wieku formą odpowiedzi do osób prywatnych ${ }^{10}$. Od każdej reguły jest wyjątek. Okazuje się bowiem, że cesarze rzymscy wysyłali również epistulae do osób prywatnych, ale tylko wówczas, gdy adresat prezentował wysoki status społeczny ${ }^{11}$.

W nauce dopiero w 1920 roku istota i funkcje reskryptów zostały gruntownie przedstawione. $\mathrm{W}$ tym właśnie roku wybitny papirolog Ulrich Wilcken dokonał niezwykle istotnej rewizji w dotychczasowych badaniach nad reskryptami ${ }^{12}$. Wilcken ukazał wyraźny podział reskryptów na subscriptiones i epistulae pod względem podmiotowości petenta. Przed tą publikacją takie rozróżnienie reskryptów nie istniało w nauce. Na przykład Theodor Kipp zaprezentował podział reskryptów, określając epistulae jako pisemne rozporządzenia cesarza do określonego adresata, natomiast subscriptiones jako rozporządzenia na złożoną prośbę ${ }^{13}$. Naukowe ustalenia Wilckena w swym ogólnym zarysie obroniły się we współczesnej nauce ${ }^{14}$. Reskrypty stanowiły pisemne odpowiedzi cesarza na zapytania urzędników (relatio, consultatio, suggestio) lub na zapytania bądź petycje osób prywatnych (prex, libellus, supplicatio) ${ }^{15}$. Wilcken stwierdził, że reskrypty to „alle kaiserliche Bescheide an Behörden, Körperscha-

9 A.A. Schiller, Roman law, s. 478-479.

10 W.W. Buckland, A Textbook, s. 18-19; D. Ibbetson, High, s. 196.

11 Por. W. Williams, The Libellus, s. 87-88.

12 U. Wilcken, Zu den Kaiserreskripten, s. 1-42. L. Wenger (Die Quellen, s. 427-428, przypis 31) przedstawił obszerną literaturę dotyczącą reskryptów.

13 Th. Kipp, Geschichte, s. 73: „Schriftliche Erlasse des Kaisers an eine bestimmte Adresse sind epistolae, und wenn sie unter eine Eingabe gesetzt sind, subscriptiones".

14 Por. W. Williams, The Libellus, s. 87.

15 W.W. Buckland, A Textbook, s. 18-19; A. Berger, Enciclopedic, s.v. rescripta principum, s. 680; A.A. Schiller, Roman law, s. 493. 
ften oder Private zusammenfaßt, die als Antwort auf ein Gesuch (oder Anfrage oder dgl.) an den Gesuchsteller erlassen sind" ${ }^{16}$.

Początkowo reskrypty nie prowadziły do zmiany prawa, lecz do jego wyjaśnienia, w materii interesującej wnioskodawcę ${ }^{17}$. Materia prawna nie dotyczyła intelektualnych rozważań nad danym zagadnieniem, lecz rzeczywistych kwestii natury praktycznej. William Turpin wyraził to w trafnym stwierdzeniu, że "petitioners went to the imperial government to get action, not advice"18. Tego typu konstytucje wyrażały cesarską opinię w kwestii prawnej lub innej specyficznej sprawie ${ }^{19}$. W przypadku subscriptiones ta specyficzna sprawa nie musiała dotyczyć kwestii prawnej; petenci chcieli również zaszczytów, urzędów czy też zezwoleń finansowych ${ }^{20}$. Wielu petentów pragnących wyjaśnienia kwestii prawnej otrzymywało subscriptiones, które nie dawały takiego wyjaśnienia, lecz odsyłały jednostkę do sądów niższej instancji ${ }^{21}$.

O wzroście znaczenia rescripta w czasach Trajana i Hadriana świadczą dane liczbowe. Według Davida Ibbetsona znamy 20 tych konstytucji $z$ okresu od panowania Augusta do epoki Trajana, natomiast aż 126 z czasów Hadriana ${ }^{22}$. Z kolei Jean-Pierre Coriat dla epoki Sewerów (lata 193-235) wyliczył 1365 konstytucji cesarskich (décisions législatives), z czego 68 stanowiły dekrety, 15 edykty, 4 - mandaty, a 1200 - reskrypty ${ }^{23}$. Od panowania Hadriana reskrypty stały się powszechne, a problemy prawne były częściej rozwiązywane przez cesarza niż przez urzędników o kompetencjach sądowych ${ }^{24}$. Przyczynę tych zmian trudno jednoznacznie wskazać. Na przykład De Francisci powiązał wzrost liczby reskryptów za

16 U. Wilcken, Zu den Kaiserreskripten, s. 2.

17 S. Brassloff, s.v. epistula, s. 205; W.W. Buckland, A Textbook, s. 19; W. Turpin, Imperial, s. 101.

18 W. Turpin, Imperial, s. 102.

19 A. Berger, Enciclopedic, s.v. rescripta principum, s. 680.

20 W. Turpin, Imperial, s. 102. Por. F. Millar, Emperors, s. 13.

21 W. Turpin, Imperial, s. 102. Takie subscriptiones nie były brane pod uwagę przez prawników w ich dziełach i kodeksach prawa.

22 D. Ibbetson, High, s. 197.

23 J.-P. Coriat, Le prince législateur, s. 156-157.

24 W.W. Buckland, A Textbook, s. 19; A.A. Schiller, Roman law, s. 491. Por. L. Wenger, Die Quellen, s. 431. 
czasów Hadriana z reorganizacją kancelarii cesarskiej, polegającą na całkowitym rozdzieleniu dotychczasowych kompetencji sekretarza między poszczególne sekretariaty; od tej pory zatem sekretariat do spraw petycji miał zajmować się wyłącznie reskryptami, sekretariat do spraw korespondencji był odpowiedzialny za przygotowywanie listów $\mathrm{z}$ odpowiedziami na zapytania poszczególnych urzędników, natomiast sekretariat a cognitionibus - za cesarskie wyroki $(\text { decreta })^{25}$. Niektórzy uczeni dopatrywali się wzrostu znaczenia reskryptów jako źródła prawa w przerwaniu mocy legislacyjnej prawa pretorskiego za panowania Hadriana ${ }^{26}$. William Warwick Buckland stwierdził, że procedura apelacyjna przed cesarzem została zastąpiona cesarskimi decyzjami dającymi odpowiedzi w kwestiach prawnych, które były brane pod uwagę przez urzędników o kompetencjach sądowych lub przez strony procesu sądowego ${ }^{27}$. Jeśli strona procesu sądowego uznała - ujęty w reskrypcie stwierdzony stan faktyczny, to nie miała już możliwości odwołania się od reskryptu. Stwierdzony w reskrypcie stan prawny był odtąd brany pod uwagę w analogicznych przypadkach ${ }^{28}$. Cesarska odpowiedź na petycję mogła być zastosowana jedynie w przypadku, gdy sąd dopatrzył się w konkretnej sprawie stanu faktycznego tożsamego $z$ tym przedstawionym $\mathrm{w}$ treści danego reskryptu ${ }^{29}$. Wydaje się zatem, że De Francisci miał rację, wysuwając tezę, że wzrost znaczenia i liczby reskryptów za panowania Hadriana był bezpośrednio związany z postępującą profesjonalizacją sekretariatów $a b$ epistulis i a libellis. Znamiennym przejawem tego procesu było powierzenie wspomnianych urzędów wykształconym i kompetentnym ekwitom ${ }^{30}$.

25 Podaję za A.A. Schiller, Roman law, s. 480.

26 O. Karlowa, Römische, s. 650; W.W. Buckland, A Textbook, s. 19.

27 W.W. Buckland, A Textbook, s. 19.

28 S. Brassloff, s.v. epistula, col. 205. Według S. Brassloffa (s.v. epistula, s. 205) epistulae principis stanowiły constitutiones personales albo generales.

29 Th. Kipp, Geschichte der quellen des römischen Rechts, Leipzig 1909, s. 74-75; A.A. Schiller, Roman law, s. 492.

30 Szerzej na ten temat zob. K. Kłodziński, Sekretarze ab epistulis, s. $51-64,73-79$. 
Dwie formy reskryptów są łączone przez jedną wspólną cechę, która stanowi reakcję cesarza na petycje różnych podmiotów ${ }^{31}$. Epistulae przyjmowały formę listu adresowanego do petenta, natomiast subscriptiones formę noty, dołączonej u dołu dokumentu oryginalnej petycji. W przypadku subscriptiones brakowało oficjalnych formuł dyplomatycznych, które to występowały w epistulae ${ }^{32}$. Otto Karlowa wskazuje, że cesarze podpisywali własnoręcznie ważne epistulae $e^{33}$. Współcześni uczeni nie dokonują takiego rozróżnienia. Uważają, że wszystkie epistulae kończyły się pożegnaniem (vale,

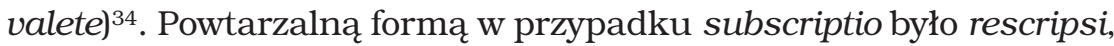
scripsi i recognovi ${ }^{35}$. Tony Honoré podaje za Ulrichem Wilckenem, że formuła dyplomatyczna recognovi była sygnowana ręką urzędnika a libellis, a rescripsi/scripsi ręką samego cesarza ${ }^{36}$. Inaczej uważa F. Millar, który twierdzi, że pisane osobiście przez cesarza dwa słowa: re(scripsi) i recognovi nadawały moc prawną danej konstytucji ${ }^{37}$. Epistulae w swej istocie były listami prywatnymi, których treść znał jedynie odbiorca ${ }^{38}$. Często odbiorca epistulae jako osoba sprawująca urząd państwowy decydował się na upublicznienie treści, jeśli ta dotyczyła sfery publicznej. Olivia Fiona Robinson

${ }^{31}$ D. Ibbetson, High, s. 196.

${ }^{32}$ Subscriptiones przybierały różne formy, por. U. Wilcken, Zu den Kaiserreskripten, s. $7-8$.

33 O. Karlowa, Römische, s. 540; Cass. Dio, 69, 1.

${ }^{34}$ W. Williams, The Libellus, s. 87; A.A. Schiller, Roman law, s. 493; por. HA, Commodus 13, 7.

35 Th. Mommsen, Gordians, s. 179; U. Wilcken, Zu den Kaiserreskripten, s. 7-9; B. Kübler, s.v. subscriptio, col. 497-498; por. W. Williams, The Libellus, s. 87.

${ }^{36}$ T. Honoré, Emperors, s. 24, przypis 2. Na temat cesarskich podpisów zob. HA, Commodus 13, 7; Tacitus 6; Carinus 15. Na petycji (CIL VIII 10570 = ILS 6870) skierowanej przez kolonów z Saltus Burunitanus do Kommodusa widnieje napis: vestramq(ue) divinam subscriptionem / adlegantibus oraz secundum / sacram subscriptionem domini n(ostri) / sanctissimi Imp(eratoris); CIL VI $3770=$ CIL VI 31330.

37 F. Millar, The Emperor, s. 248.

${ }^{38}$ Epistulae łacińskie znajdujemy w treści inskrypcji, Digestach oraz kodeksach prawa, natomiast greckie w treści inskrypcji i papirusów, por. A.A. Schiller, Roman law, s. 496. 
sądzi, że dokument z subscriptio lub jego kopia był wysyłany do indywidualnego petenta ${ }^{39}$. Nie jest to opinio communis. Niektórzy uważają, że subscriptiones były wysyłane do miejsc publicznych, w pobliżu rezydencji cesarza (świątynia Apolla w II wieku), gdzie decyzja cesarska była czytana i kopiowana przez osoby zainteresowane $^{40}$. Moim zdaniem, uwzględniając charakter podmiotów oraz ich stosunkowo niski status społeczny, jedynie epistulae były dostarczane bezpośrednio ${ }^{41}$. Nie zmienia to faktu, że subscriptiones przez swą powszechność i publiczny charakter stanowiły w porównaniu z epistulae bardziej doniosłą formę dokumentu prawnego ${ }^{42}$. Wiliam Turpin stwierdził, że ogólna ewidencja źródłowa przedstawia liczbę ponad 2500 subscriptiones, które zostały zawarte głównie w dwóch zbiorach konstytucji z czasów Dioklecjana - Codex Gregorianus, Codex Hermogenianus oraz w jednej z trzech części wielkiej kompilacji z czasów Justyniana Wielkiego - Codex Iustinianus ${ }^{43}$.

W tym miejscu warto zastanowić się nad pytaniami postawionymi na samym wstępie rozważań. Wielu przedstawicieli zarówno starszej, jak i nowszej nauki poprzestaje w swych rozważaniach na ogólnym stwierdzeniu, że epistulae były opracowywane przez sekretarzy do spraw korespondencji - ab epistulis (Latinis i Graecis), natomiast subscriptiones przez sekretarzy do spraw petycji - a libellis ${ }^{44}$. Znaleźli się jednak uczeni, którzy poddali kwestię autorstwa reskryptów szczegółowym badaniom. Wydaje się, że jako pierwszy głos w tej materii zabrał Adrian Nicholas Sherwin-White, który pod kątem ustalenia autorstwa reskryptów przeanalizował korespon-

\footnotetext{
39 O.F. Robinson, The Sources, s. 36.

40 Por. W. Williams, The Libellus, s. 87; A.A. Schiller, Roman law, s. 500-501 .

41 Por. W. Turpin, Imperial, s. 101.

42 D. Ibbetson, High, s. 196-197; por. W. Turpin, Imperial, s. 102.

43 W. Turpin, Imperial Subscriptions, s. 101-102.

44 O. Karlowa, Römische, s. 651; U. Wilcken, Zu den Kaiserreskripten, s. 10; W.W. Buckland, A Textbook, s. 18-19; W. Williams, The Libellus, s. 86; A. Guarino, Gli aspetti giuridici del principato, Aufstieg und Niedergang der römischen Welt 1980, ed. H. Temporini, II, 13, s. 16. O.F. Robinson, The Sources, s. 34; D. Ibbetson, High, s. 196; A. Berger, Enciclopedic, s.v. epistulae principum, s. 454.
} 
dencję cesarza Trajana $z$ Pliniuszem Młodszym ${ }^{45}$. Brytyjski historyk na podstawie analizy słownictwa, frazeologii, typowych terminów i administracyjnego żargonu stwierdził, że formalna ręka sekretarzy cesarskich jest widoczna w wielu reskryptach, które zostały sporządzone w oparciu o - jak to określa autor - bureaucratic langu$a g e^{46} . Z$ kolei rozpoznanie w treści reskryptów wyrażenia myśli oraz języka Trajana nie należy wprawdzie do łatwych, lecz jest dostrzegalne w kilku przypadkach ${ }^{47}$. Na przykład gdy cesarz zdecydowanie odmawia prośby ${ }^{48}$ lub gdy oświadcza, że nie będzie podejmował decyzji w błahej sprawie ${ }^{49}$. Pewnym mankamentem, który uniemożliwia sformułowanie ogólnych wniosków, jest fakt, że rozważania Sherwin-White’a są oparte na jednym źródle. Głos w kwestii autorstwa reskryptów cesarskich zabrał także Fergus Millar, który uwzględniając różnego rodzaju źródła, wykazał, że zainteresowani sprawami państwa cesarze, tacy jak Oktawian August, Kaligula, Neron, Tytus, Marek Aureliusz, Kommodus, Aleksander Sewer, nie stronili od konfrontacji stron sporu, wysłuchiwania petentów, odpisywania na libelli, przyjmowania delegacji czy też wydawania różnych decyzji ${ }^{50}$. Dyktowanie przez cesarzy listów do miast lub urzędników stanowiło normalną praktykęę . Cesarze rzymscy układali swe własne wypowiedzi tak pisemne, jak i ustne ${ }^{52} . Z$ badań F. Millara wynika, że byli oni bardzo zajęci, gdyż osobiście angażowali się m.in. w proces tworzenia konstytucji. W procesie tym zdaniem Millara brał również udział niedoceniany przez źródła literackie sekretariat, który był odpowiedzialny za szeroki zakres spraw cesar-

45 A.N. Sherwin-White, Trajan's Replies to Pliny: Authorship and Necessity, The Journal of Roman Studies 1962, 52, s. 114-125.

46 A.N. Sherwin-White, Trajan's Replies, s. 116.

47 Ibidem, s. 115.

48 Traianus, Plinio, Ep. 40, 3.

49 Traianus, Epp. 82, 117.

50 F. Millar, Emperors, s. 9-19. Millar rozszerzył swą argumentację w wydanej w Londynie w 1977 roku pracy pt. The Emperor in the Roman World, 31 BC-AD 337.

51 Na przykład cesarz Kaligula podyktował odpowiedź sekretarzowi $a b$ epistulis po przeczytaniu listu od Petroniusza, Philo, Leg. 258-260.

52 F. Millar, Emperors, s. 19. 
skich $^{53}$. Wynne Williams dowiódł natomiast, jak dalece indywidualne postawy i zwyczaje cesarzy wpływały na ostateczną treść konstytucji cesarskich, które w większości dla omawianego okresu zachowały się na inskrypcjach, czyli w postaci pozajurydycznej54. Williams zauważył również, że badania Millara i Sherwin-White’a mogą dowodzić poprawności hipotezy o „universal imperial authorship”, która mówi o istnieniu we wszystkich konstytucjach cech indywidualnego stylu cesarzy mającego wyraz w określonych standardowych formułach $^{55}$. Według Williamsa jednak ani to, że cesarze osobiście formułowali niektóre dokumenty, ani to, że istniały dokumenty bez wyraźnego wpływu cesarzy na ich treść, nie dowodzi słuszności hipotezy o „universal imperial authorship" 56 . Williams stwierdził, że stylistyczna analiza pokazuje przypadki, w których osobiście cesarze zarówno wydawali decyzje, jak i tworzyli ostateczny tekst odpowiedzi prawnych. Angielski badacz nie wykluczył jednak, że w przypadku rutynowych spraw to ostatnie zadanie było wykonywane przez sekretarzy $a b$ epistulis i a libellis ${ }^{57}$. Do reskryptów sporządzanych przez sekretarzy badacz zaliczył epistulae o formalnym i dyplomatycznym charakterze, w szczególności te, które były adresowane do miast greckich; edykty, które w sferze publicznej były przejawem euergetyzmu cesarskiego, oraz subscriptiones, w których cesarz za pośrednictwem swych sekretarzy udzielał porad prawnych.

Wszyscy trzej badacze, których zdania przytoczyłem, są zgodni co do zasady dychotomicznego podziału analizowanych aktów prawnych; według nich reskrypty były bowiem tworzone zarówno przez cesarzy, jak i sekretarzy. Całkowicie inne, oryginalne zdanie w tej kwestii miał historyk prawa rzymskiego Tony Honoré, który opierając się głównie na zbiorze konstytucji cesarskich zawartych w wielkiej kompilacji prawa rzymskiego z czasów Justyniana Wielkiego, przekonywał, nie wykluczając oczywiście udziału cesarzy, że wyłącznie sekretarze do spraw petycji sporządzali odpowiedzi na zapytania

53 Ibidem: vast ranges of imperial business were handled by the bureaux in private, systematically concealed from of our literary sources.

54 W. Williams, Individuality, s. 67.

55 Ibidem, s. 67-68.

56 Ibidem, s. 68.

57 Ibidem. 
indywidualnych petentów ${ }^{58}$. Wybitny romanista dostrzegł pewne korelacje między stylem języka dzieł poszczególnych prawników a stylem treści reskryptów powstałych w czasie, w którym oni sprawowali urząd a libellis. Na podstawie porównania dzieł prawnych z reskryptami Honoré ustalił na przykład, że wybitni juryści i późniejsi prefekci pretorianów Emiliusz Papinian i Domicjusz Ulpian byli sekretarzami do spraw petycji, kolejno: Papinian od 26 września 194 do 12 lutego 202 roku, Ulpian - od 25 marca 202 do 1 maja 209 roku $^{59}$. Reskrypty $z$ tych lat są pisane wysoce technicznym językiem, ręką profesjonalnych prawników ${ }^{60}$. Honoré badał reskrypty w oparciu o szczegółowe kryteria, takie jak długość reskryptu, składnia językowa, słownictwo, logiczna i dialektyczna struktura czy też nastawienie na podstawowe problemy prawne ${ }^{61}$. Brian Campbell zaobserwował jednak trafnie, że przedstawione przeze mnie argumenty uczonych nie rozstrzygają problemu autorstwa reskryptów62. Angielski badacz słusznie zauważył, że sekretarz a libellis mógł wyrazić własnymi słowami i stylem decyzję skutecznie wydaną przez cesarza lub jego radę. Tą samą drogą zwrócił także uwagę, że charakter indywidualności cesarskich dokumentów można wyjaśnić, stawiając hipotezę, iż kompetentni sekretarze przyjmowali persona i ton swoich władców ${ }^{63}$. Cesarz równie dobrze mógł osobiście rozpatrywać petycje, jak również delegować te sprawy podległym urzędnikom. Co ciekawe, już starożytni zastanawiali się nad autorstwem konstytucji cesarskich. W 163 roku Korneliusz Fronton skierował do cesarza Lucjusza Werusa pytanie: Quis edictum, quis epistulam suismet verbis componere potuit?64. Jaką rolę $\mathrm{w}$ procesie tworzenia konstytucji odgrywali sekretarze ab epistulis i a libellis? Czy zajmowali się podejmowaniem decyzji wykonawczych, przygotowaniem gotowych dokumentów przedstawianych cesarzowi do

58 T. Honoré, Emperors, s. 46-49.

59 Ibidem, s. 144.

60 Ibidem, s. 52.

61 Ibidem, s. 50-52.

62 J.B. Campbell, The Emperor and the Roman Army, 31 BC-AD 235, Oxford 1984, s. 265.

63 Ibidem.

64 Fronto, Ad Verum III, 7. 
zatwierdzenia, czy też dawaniem technicznych porad, np. w kwestiach prawnych dotyczących greckojęzycznych prowincji?

Większość źródeł opisujących czasy pryncypatu przedstawia nie funkcje czy zadania sekretarzy, lecz ich potentia (to jest potęgę, znaczenie, wpływy) ${ }^{65}$. $Z$ tego też względu ustalenie całościowego zakresu zadań nie należy do łatwych ${ }^{66}$. $Z$ pewnością głównym zadaniem sekretarzy ab epistulis było pisanie oficjalnych i urzędowych listów, o ile nie były one sporządzone osobiście przez pryncepsów ${ }^{67}$. Jakiego typu były to listy i jakiej treści dotyczyły? Z pewnością nominacje wybranych przez cesarza najwyższych urzędników - ekwickich prokuratorów, wielkich prefektów, wysokich urzędników pałacowych oraz oficerów wojskowych - odbywały się przez wysyłanie codicilles, które przyjmowały formę zawiadamiającego o nominacji listu sporządzanego przez sekretarzy ab epistulis ${ }^{68}$. Millar wskazuje, że codicilles mogły być osobiście dyktowane, a nawet sporządzane przez cesarzy ${ }^{69}$. Stwierdzenie to może potwierdzać zachowany na inskrypcji, skierowany przez Marka Aureliusza do prokuratora Q. Domitiusa Marsianusa w formie codicillus zwrot vale mi Marsiane karissime/ $m i h i^{70}$. Również nadawanie przywilejów cesarskich dla pojedynczych osób lub korporacji przyjmowało formę listów ${ }^{71}$. Taką formę miało

65 Por. F. Millar, Rome, s. 14.

${ }^{66}$ Por. A.A. Schiller, Roman law, s. 480.

67 É. Cuq, Le Conseil, s. 392; O. Karlowa, Römische, s. 544; A.H.J. Greenidge, Roman, s. 419; O. Hirschfeld, Die kaiserlichen, s. 323-324; por. Th. Mommsen, Römisches, s. 809.

68 O. Karlowa, Römische, s. 541, 544. Swetoniusz podaje, że będący w Judei Wespazjan cofnął nominację prefektowi jazdy, Suet., Vespasianus 8; Wegecjusz wspomina, że o wyborze trybunów większych (tribunus maior) decyduje cesarz poprzez sacram epistolam, Vegetius, 2, 7. Z kolei dla tworzenia aktów nominacyjnych urzędników senatorskich został powołany urząd - a codicillis, O. Karlowa, Römische, s. 541; O. Hirschfeld, Die kaiserlichen, s. 322, przypis 2 . W świetle prawa rzymskiego codicillus mógł być sporządzany w formie listu lub pisemnej prośby, C., 6, 42, 22.

${ }^{69}$ F. Millar, Rome, s. 10. Por. Epictetus, 3, 7, 30; Suet., Cal. 18; Suet., Claud. 29.

70 AE 1962, 183.

${ }^{71}$ O. Karlowa, Römische, s. 544; O. Hirschfeld, Die kaiserlichen, s. 322; S. Brassloff, s.v. epistula, col. 205; por. R. Paribeni, s.v. ab epistulis, s. 2133-2134. 
chociażby uprawnienie do czerpania wody ${ }^{72}$, prerogatywy ludności żydowskiej i syryjskiej ${ }^{73}$ czy też nadanie prawa latyńskiego ${ }^{74}$. $Z$ sekretariatu $a b$ epistulis wypływały także cesarskie odpowiedzi na listy namiestników i dowódców wojskowych oraz na sprawozdania i zapytania (relatio, consultatio, suggestio) urzędników ${ }^{75}$. Prowadzenie oficjalnych stosunków z gminami miejskimi i korporacjami oraz przyjmowanie od uzależnionych ludów deputacji należało również do zadań sekretariatu ab epistulis ${ }^{76}$. Urzędnicy ab epistulis byli także przedstawicielami cesarzy w pertraktacjach wojennych ${ }^{77}$. Księga Sudy, opisując kompetencje sekretarza, mówi pośrednio o tej kompetencji ${ }^{78}$. Sekretarze tworzyli i wysyłali listy, które - podkreślam - nie były pisane własnoręcznie przez cesarzy ${ }^{79}$.

72 Frontinus, de aquis 103: ne quis sine litteris Caesaris, id est ne quis aquam publicam non impetratam... ducat; 105: Qui aquam in usus privatos deducere volet, impetrare eam debebit et a principe epistulam ad curatorem adferre. Frontinus wskazuje, że każdy, kto zechce czerpać wodę dla prywatnego użytku, musi mieć pisemną zgodę od cesarza.

73 Iosephus, Ant. Jud. 20, 8, 9.

74 Gaius, 1, 96: aut maius est latium aut minus: maius est Latium, cum ei hi qui decuriones leguntur et ei qui honorem aliquem aut magistratum gerunt civitatem Romanam consecuntur; minus Latium est, cum hi tantum qui magistratum vel honorem gerunt ad civitatem Romanam perueniunt: idque compluribus epistulis principum significatur. Rozróżnienie na prawo latyńskie większe i mniejsze przyjmowało formę cesarskiego listu.

75 O. Karlowa, Römische, s. 544; O. Hirschfeld, Die kaiserlichen, s. 323;

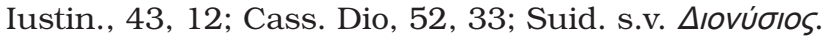

76 É. Cuq, Le Conseil, s. 393; O. Hirschfeld, Die kaiserlichen, s. 323. W późnym Cesarstwie Rzymskim magister epistolarum legationes civitatum cosultationes et preces tractat, Notit. Dign. Or., C. 19; Occ., C. 17. Jedna epistula cesarza Konstantyna Wielkiego mówi o ochronie przed fiskusem cesarskim i wolności od podatków, którymi to cieszyli się weterani, C.Th., $12,46,2$.

77 Publius Taruttienus Paternus, ab epistulis Latinis w kancelarii cesarza Marka Aureliusza, prowadził pertraktacje z Kotynami, którzy nie podjęli walki przeciwko Markomanom (Cass. Dio, 71, 12, 3). Por. F. Millar, Emperors, Frontiers and Foreign Relations, 31 B.C. to A.D. 378, Britannia 1982, 13, s. 5-6.

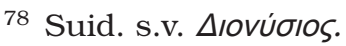

79 Por. O. Hirschfeld, Die kaiserlichen, s. 323-324, przypis 2. 
Otto Hirschfeld sądzi, że korespondencja cesarza Trajana z namiestnikiem Bitynii Pliniuszem może świadczyć, iż jedynie krótkie instrukcje do najwyższych urzędników prowincjonalnych, czyli mandata, mogły być sporządzane osobiście przez cesarzy ${ }^{80}$. Epistolarna forma mandata wskazuje na tworzenie tych dokumentów przez ab epistulis, co niejako obala słuszność tego stwierdzenia ${ }^{81}$. Prywatna korespondencja cesarzy była zapewne wyłączona $z$ biura ab epistulis, choć nie jest wykluczone, że prywatna i tajna korespondencja była pod opieką prywatnych sekretarzy ${ }^{82}$. Wydaje się, że cesarze stale mieli sekretarza do spraw prywatnej i tajnej korespondencji ${ }^{83}$.

$Z$ kolei podstawowym zadaniem sekretarzy a libellis było zajmowanie się adresowanymi do cesarza, sporządzonymi na piśmie, zapytaniami i prośbami (preces, libelli, supplicationes) od osób prywatnych $^{84}$. Urzędnicy a libellis przygotowywali odpowiedzi na zapytania i prośby, które były prawnie opracowywane, a następnie przedstawiane cesarzowi do akceptacji i krótkiej własnoręcznej noty (subscriptio) $^{85}$. Cesarska nota nabrała dużego znaczenia za panowania Hadriana, a w czasach późniejszych miała moc ustawy w sprawach odpowiedzi na petycje osób prywatnych ${ }^{86}$.

80 O. Hirschfeld, Die kaiserlichen, s. 323-324, przypis 2.

81 D. 47, 11, 6 (Ulp., libro octavo de officio proconsulis). Za cesarzy $z$ dynastii flawijskiej funkcjonował custos a mandatis, CIL VI 8814. Procurator a mandatis jest potwierdzony dopiero za panowania Aleksandra Sewera, CIL III 536 = ILS 1575.

82 O. Hirschfeld, Die kaiserlichen, s. 324.

83 Cass. Dio, 60, 34, 5; por. Cass. Dio, 71, 29, Suet., Augustus 67.

84 Seneca, ad Polybi 6, 5: audienda sunt tot hominum milia, tot disponendi libelli; tantus rerum ex orbe toto coeuntium congestus, ut possit per ordinem suum principis maximi animo subici, exigendus est; por. 6: adsidua laboriosi officii statione fatigatum corpus.

85 O. Karlowa, Römische, s. 544-545. O. Hirschfeld, Die kaiserlichen, s. 327-328. Por. A.H.J. Greenidge, Roman, s. 419; F. Millar, Emperors, s. 17. Na temat cesarskich not zob. HA, Commodus 13, 7; Tacitus 6; Carinus 15. Na petycji (CIL VIII 10570 = ILS 6870) skierowanej przez kolonów z Saltus Burunitanus do Kommodusa widnieje napis: vestramq(ue) divinam subscriptionem / adlegantibus oraz secundum / sacram subscriptionem domini n(ostri) / sanctissimi Imp(eratoris).

86 O. Hirschfeld, Die kaiserlichen, s. 328; HA, Macrinus 13: cum Traianus numquam libellis responderit, ne ad alias causas facta praeferrentur quae 
O dużym znaczeniu subscriptio w czasach Hadriana świadczy passus Gajusa:

Gaius, Institutiones 1, 94:

Item si quis cum uxore praegnante civitate Romana donatus sit, quamvis is, qui nascitur, ut supra dixi, civis Romanus sit, tamen in potestate patris non fit: Idque subscriptione divi sacratissimi Hadriani significatur qua de causa, qui intellegit uxorem suam esse praegnantem, dum civitatem sibi et uxori ab imperatore petit, simul ab eodem petere debet, ut eum, qui natus erit, in potestate sua habeat.

Wypada zgodzić się ze zdaniem Davida Ibbetsona, który twierdzi, że specjalistyczna wiedza $z$ zakresu prawa była warunkiem wstępnym do objęcia sekretariatu a libellis ${ }^{87}$. Jest zrozumiałe, że pełniący urząd a libellis wybitni juryści - Volusius Maecianus ${ }^{88}$ za Marka Aureliusza, Marcus Aurelius Papirius Dionysius ${ }^{89}$ za Kommodusa oraz sprawujący urząd magister libellorum powszechnie cenieni Emiliusz Papinian ${ }^{90}$ za Septymiusza Sewera czy też prawdopodobnie Domicjusz Ulpian ${ }^{91}$ za Karakalli - byli niezwykle biegli w zakresie wiedzy prawniczej. $Z$ okresu poklasycznego znamy dwóch

ad gratiam composita viderentur. Respondere oznacza udzielanie prawnej opinii, O. Hirschfeld, Die kaiserlichen, s. 328, przypis 2. Ammianus Marcellinus określa magister libellorum jako libellis respondens (Amm. Marc., $20,9,8)$. Natomiast facta oznaczają sententiae iuris albo rescripta, O. Hirschfeld, Die kaiserlichen, s. 328, przypis 2. Th. Mommsen (Gordians, s. 187, przypis 3), porównując profferentur i praeferrentur, zauważa, że cesarz Trajan zaniechał dawania pouczeń prawnych w tej kwestii.

87 D. Ibbetson, High, s. 184.

88 PIR V 657; G. Samonati, s.v. a libellis, s. 826-827.

89 PIR A 883; PIR² A 1567; É. Cuq, Le Conseil, s. 365; L. Friedlaender, Darstellungen, s. 179; P. von Rohden, s.v. M. Aurelius Papirius Dionysius, RE II, 1896, col. 2515; J. Crook, Consilium principis. Imperial counsils and counsellors from Augustus to Diocletian, Cambridge 1955, s. 154, nr 53; G. Samonati, s.v. a libellis, s. 827-828.
90 D. 20, 5, 12.
${ }^{91}$ HA, Niger 7. 
jurystów, którzy działali jako magistri libellorum. Byli nimi Aurelius Arcadius Charisius i Hermogenianus ${ }^{92}$.

Z późnoantycznego źródła Notitia Dignitatum wynika, że w IV wieku nie tylko pisemne prośby (preces), ale również zlecone przez cesarza prawne dochodzenia (cognitiones) należały do zadań magister libellorum ${ }^{93}$. Początków specjalizacji urzędniczej w tym kierunku możemy dopatrywać się już pod koniec II wieku ${ }^{94}$. Kariera przytoczonego wyżej, sprawującego stanowiska a libellis $i$ a cognitionibus za Kommodusa Papiriusa Dionysiusa stanowi dostateczne potwierdzenie tej hipotezy.

Niektóre prośby osób prywatnych były rozpatrywane osobiście przez cesarza ${ }^{95}$. Sententiae i epistulae to dwa przykłady petycji per libellum z ustnymi odpowiedziami cesarza ${ }^{96}$. Możliwe jest także, że a libellis nie tylko zajmował się pisemnymi prośbami, ale również wysłuchiwał petentów ${ }^{97}$. Éduard Cuq sądzi, że sekretarze od petycji wysłuchiwali wiele próśb osób prywatnych (postulatores), które liczyły na litość i życzliwość cesarza ${ }^{98}$. Przed tymi urzędnikami przedkładano również prośby o zwolnienie $z$ opieki, o nowy status

92 D. Ibbetson, High, s. 184, przypis 4.

93 Notit. Dign. Or., C. 19; Occ., C. 17: magister libellorum cognitiones et preces tractat; por. CIL VI 510 = ILS 4152: magister libellorum et cognitionum sacrarum; É. Cuq, Le Conseil, s. 383-384; E. De Ruggiero, Diz. epigr., vol. II, parte I, 1900, 321.

94 Por. É. Cuq, Le Conseil, s. 384. Otto Karlowa (Römische, s. 545) uważa, iż w późniejszym czasie urząd a cognitionibus został włączony do sekretariatu a libellis.

95 Oktawian August przyjmował osobiście prośby petentów (Suetonius, Augustus 53). Z kolei cesarz Domicjan upokorzył filozofa Euphratesa przez przeczytanie na głos prośby, którą ten mu wręczył w zaufaniu (Philostr., V. Apollon. 5, 38). Z pewnością do przebywającego na prowincjach cesarza Hadriana napływały nieustannie różnego rodzaju prośby. Kasjusz Dion opisuje sytuację, w której cesarz musiał ulec i wysłuchać prośby zdesperowanej i odważnej kobiety, Cass. Dio, 69, 6, 2-3.

96 Por. F. Millar, Emperors, s. 11.

97 A. Berger, Enciclopedic, s.v. a libellis, s. 338: The head of the division of the imperial chancery which dealt with all kinds of petitions adressed to the emperor. His later title was magister libellorum.

98 É. Cuq, Le Conseil, s. 366: Il avait à écouter ces milliers de solliciteurs (postulatores) qui vanaient tout en larmes faire appel à la pitié de leur très 
miast, błagano także cesarza o osobiste wydanie wyroku w procesie $^{99}$, jak również o wykładnię w niejasnych kwestiach prawnych ${ }^{100}$. Mieszkańcy miast zabiegali o pojedyncze zwolnienia podatkowe ${ }^{101}$ czy też o zmianę kwestii cenzusowych ${ }^{102}$, tudzież mieszkańcy prowincji prosili cesarza o zmniejszenie tributum ${ }^{103}$.

$Z$ podjętych rozważań wynika, że definitywne ustalenie zakresu obowiązków, które były powierzane sekretarzom, podobnie jak ustalenie autorstwa reskryptów, nie jest możliwe ${ }^{104}$. Przeprowadzone przez historyków, romanistów i filologów badania nie pozwoliły na jednoznaczne ustalenie tego, czy osobiście sam cesarz, czy też sekretarze tworzyli reskrypty. Twierdzenie, że cesarze rzymscy tworzyli osobiście prawo, jest swego rodzaju eufemizmem, gdyż to właśnie zaznajomieni w dziedzinie prawa urzędnicy kancelarii cesarskiej byli współkreatorami konstytucji cesarskich. W okresie pryncypatu sprawne wykonywanie władzy musiało być realizowane poprzez rozbudowany aparat urzędniczy. Sekretarze ab epistulis i a libellis, obok a rationibus, a cognitionibus, a studiis, a memoria i a commentariis, stanowili niezwykle ważny element machiny biu-

doux empereur. W swym stwierdzeniu É. Cuq (Le Conseil, s. 366, przypis 2) opiera się na przykładzie petycji z odpowiedzią cesarza, która została zawarta w De lege Rodia, D. 14, 2.

${ }^{99} \mathrm{~W}$ prawie rzymskim istniała możliwość osobistego rozpatrywania próśb przez cesarza, D. 49, 5, 5, 1 (Ulp. libro quatro de appellationibus). Na przykład w kwestii wyboru prawnego spadkobiercy zwrócono się do cesarzy, D. 28, 5, 93 (92).

100 É. Cuq, Le Conseil, s. 366-367. Cesarz Septymiusz Sewer w odpowiedzi na consultatio wydał reskrypt, w którym została rozpatrzona słuszność interwencji pretora w sprawie skutków prawnych umowy zawartej przez minor viginti quinque annis, D. 4, 4, 11, 2 (Ulp, libro 11 ad edictum): Aetrius Severus quia dubitabat, ad imperatorem Severum rettulit: ad quam consultationem successori eius Venidio Quieto rescripsit.

${ }^{101}$ O zwolnieniu od podatków w zakresie prawa własności mówi skierowany do Pelignianusa reskrypt cesarski, D. 50, 15, 3, 1 (Ulp., libro secundo de censibus). O trwałym zwolnieniu miejsc i miast z podatków od własności - D. 50, 15, 4, 3.

102 O prośbie w sprawie powrotnej zmiany miejsca zamieszkania (wpisania na listę cenzusową) - D. 50, 15, 4, 10.

103 Tacitus, Ann. 2, 42.

104 Zob. J.B. Campbell, The Emperor, s. 265. 
rokratycznej w Imperium Romanum. Na koniec należy stwierdzić, że w drugiej połowie II wieku stanowisko ab epistulis Latinis było jednym ze szczebli kariery Publiusa Taruttienusa Paternusa ${ }^{105}$, znakomitego znawcy prawa wojskowego i prefekta pretorianów cesarzy Marka Aureliusza i Kommodusa, a magister libellorum za panowania Sewerów to jeden $\mathrm{z}$ urzędów w cursus honorum wybitnych jurystów Emiliusza Papiniana i Domicjusza Ulpiana.

\section{SUMMARY}

\section{The Participation of Secretaries ab epistulis and $a$ libellis in the process of creating Imperial Rescripts}

The Secretaries $a b$ epistulis and a libellis were very important element of Imperial administration. Only these high civil officials participated in creating Imperial Law. The bureau of Imperial correspondence (ab epistulis) was receiving letters from official sources, but the bureau of petitions (a libellis) was receiving the petitions addressed by private individuals to the Emperor. These central departments created two forms of Imperial Rescripts: epistulae and subscriptiones. The Emperor Hadrian reorganized the chancery, which became the state pillar of administration. Since that moment the Rescripts as Imperial Constitutions became very common. Who was responsible for creation of Imperial Rescripts? The Emperor or professional Secretaries? What tasks did the Secretaries perform? These questions have been the matter of academic discussion for a long time. Basing on Roman Law, epigraphic material and literary sources the article presents the Rescripts as a source of Roman Imperial Law. Moreover, it concentrates on the legislative participation of the Secretaries in creating Imperial Rescripts.

Keywords: ab epistulis, a libellis, Hadrian, Roman Law, Imperial Law, Imperial Rescripts, epistulae, subscriptiones

105 Na temat osoby Paternusa i jego działalności prawniczej zob. K. Kłodziński, Publius Taruttienus Paternus jako wybitny jurysta i praefectus praetorio cesarzy Marka Aureliusza i Kommodusa, Studenckie Zapiski Historyczne 2010, z. 5, s. 73-91. 